\title{
APLIKASI TEKNOLOGI FERMENTASI DALAM PEMBUATAN BIOSTARTER BERBASIS DAUN DAN BUAH DI DESA ANTAPAN BATURITI TABANAN
}

\author{
N.M. S. Sukmawati ${ }^{1}$, N. W. Suniti ${ }^{2}$ dan I N. Sujana ${ }^{3}$
}

\begin{abstract}
ABSTRAK
Kegiatan usaha tani holtikultura yang intensif di Desa Antapan, Baturiti, Tabanan, Bali telah mendorong pemakaian pupuk anorganik dan pestisida yang terus meningkat. Hal ini menyebabkan terjadinya pencemaran lingkungan dan berdampak negatif terhadap tanah, organisme yang hidup di dalam tanah, dan manusia yang mengkonsumsi produk holtikultura tersebut. Meningkatnya kesadaran masyarakat akan pentingnya menjaga kesehatan tubuh, maka mereka mulai beralih ke produk organik sehingga perlu ditunjang oleh ketersediaan pupuk organik (padat dan cair) serta biopestisida. Dalam proses pembutan pupuk dan pestisida organik ini diperlukan fermentor sebagai starter. Pada saat ini, fermentor yang dijual di pasaran sudah banyak, namun harganya relatif mahal. Untuk itu perlu dicari jalan keluar yaitu dengan membuat fermentor (starter) secara mandiri dengan memanfaatkan potensi yang ada seperti limbah buah dan daun. Tujuan dari kegiatan ini adalah untuk meningkatkan pengetahuan dan ketramplian kelompok tani Setia Makmur dalam pembuatan biostarter secara mandiri. Metode yang digunakan dalam kegiatan ini adalah penyuluhan, pelatihan dan pendampingan. Sebagai fermentor awal digunakan mikroba efektif yang sudah dibiakkan dalam molases yang terdiri dari bakteri asam laktat, bakteri fotosintetik, jamur aktinomycetes dan ragi/yeast. Hasil analisis Laboratorium menunjukkan bahwa biostarter berbasis buah memiliki kandungan bakteri asam laktat yang lebih tinggi dibanding yang berbasis daun ( $8 \times 10^{6} \mathrm{CFU} / \mathrm{ml} \mathrm{VS} 6,95 \times 10^{6} \mathrm{CFU} / \mathrm{ml}$ ) serta bebas dari E. colli dan Salmonela. Dari hasil percobaan ini dapat disimpulkan bahwa biostarter berbasis buah memiliki kualitas yang lebih baik dibanding daun.
\end{abstract}

Kata kunci : fermentasi, biostarter, daun, buah, desa Antapan

\begin{abstract}
Intensive horticulture farm activities in Antapan village, Baturiti, Tabanan, Bali caused the use of inorganic fertilizers and pesticides continue to rise. This led to the pollution of the environment and negatively impact on soil, the organisms that live in the soil, and humans who consume the horticulture products. Increasing public awareness of the importance of maintaining the health of the body, caused they started come back to organic products so that needs to be supported by the availability of organic fertilizers (liquid and solid) as well as a biopesticide. In the process of making organic fertilizers and biopesticides it needed fermenters as a starter. At this time, the fermenters sold widely, but the price is relatively expensive. It is necessary to look for a way out namely by making fermenters (starter) independently by utilizing existing potential as waste fruit and leaves. The purpose of this activity is to improve the knowledge and skill of the farmers group in the making biostarter independently. The methods used in this activity is the counseling, training and mentoring. As early effective microbes use fermenters that already were bred in the molases consisting of lactic acid bacteria, photosynthetic bacteria, actinomycetes and yeast. The results of laboratory analysis showed that biostarter-based fruit contain lactic acid bacteria is higher than that based on the leaf $(8 \times 106 \mathrm{CFU} / \mathrm{ml}$ VS. $6.95 \times 106 \mathrm{CFU} / \mathrm{ml}$ ) as well as free from E. colli and Salmonela. From the results of this experiment can be concluded that fruit-based biostarter has a better quality than the leaves.
\end{abstract}

\footnotetext{
${ }^{1}$ Dosen Fakultas Peternakan Universitas Udayana, sucisukma@unud.ac.id

${ }^{2}$ Dosen Fakultas Pertanian Universitas Udayana

${ }^{3}$ Dosen FKIP Universitas Dwijendra, Denpasar
} 
Key word : fermentation, biostarter, leaf, fruit, Antapan village .

\section{PENDAHULUAN}

Desa Antapan merupakan salah satu desa yang terletak di Kecamatan Baturiti, Tabanan dengan jarak sekitar $40 \mathrm{~km}$ sebelah utara pusat kota kabupaten Tabanan. Desa ini memiliki luas wilayah $1575 \mathrm{Ha}$, dengan pemanfaatan wilayah perkebunan 1122 ha, tegalan 11,50 ha, perumahan 28,25 ha, kuburan 0,40 ha, dan perkantoran 0,31 ha. Jumlah penduduk Desa Antapan sekitar 3111 jiwa, dengan mata pencarian hampir seluruhnya sebagai petani atau buruh tani. Dalam RPJM Kabupaten Tabanan tahun 2012-2017 Kecamatan Baturiti tepatnya di wilayah Desa Antapan dan sekitarnya ditetapkan sebagai sentra pengembangan hortikultura (sayur-sayuran)

Kegiatan usaha tani hortikultura yang intensif di desa ini telah mendorong pemakaian pupuk anorganik dan pestisida yang terus meningkat. Hal ini menyebabkan terjadinya pencemaran lingkungan dan berdampak negatif terhadap tanah, organisme yang hidup di dalam tanah, dan manusia yang mengkonsumsi produk hortikultura tersebut (Sardiana, dkk, 2014). Meningkatnya kesadaran masyarakat akan pentingnya menjaga kesehatan tubuh, maka secara perlahan-lahan mereka mulai beralih ke produk organik. Selain itu, Desa Antapan yang lokasinya berdekatan dengan objek wisata Bedugul memiliki potensi besar untuk dikembangkan sebagai daerah agrowisata sayuran organik. Untuk itu, perlu ditunjang oleh ketersediaan pupuk organik (padat dan cair) serta biopestisida. Dalam proses pembutan pupuk dan pestisida organik ini diperlukan biostarter yang berperan sebagai pengurai yang akan mempercepat proses fermentasi bahan alami menjadi nutrisi

Pada saat ini, biostarter yang dijual di pasaran sudah banyak, namun harganya relatif mahal. Oleh karena itu perlu dicari jalan keluar yaitu dengan membuat biostarter secara mandiri dengan memanfaatkan limbah yang ada di lingkungan setempat, seperti limbah buah dan daun. Percobaan ini dilakukan dengan tujuan untuk memberi gambaran kepada masyarakat tentang pembuatan biostarter (fermentor) dari bahan-bahan berbasis limbah yang ada di lingkungan setempat sehingga tidak tergantung dari biostarter buatan pabrik dan memiliki nilai ekonomi.

\section{METODE PELAKSANAAN}

Metode yang digunakan dalam kegiatan ini adalah melalui ceramah, pelatihan, dan pendampingan. Biostarter yang dibuat adalah biostarter yang berbasis buah dari limbah buah tomat dan murbay, serta dari bahan berbasis daun yaitu dari daun murbay dan limbah bunga gemitir (mery gold) dengan menggunakan fermentor mikroba efektif yang dibiakkan dalam molases. Biostarter yang sudah jadi kemudian dianalisis kandungan bakteri asam laktatnya sebagai bakteri dominan dalam biostarter. Selain itu, dianalisa juga kandungan E. colli dan Salmonella untuk memastikan keamanan dalam aplikasinya di lapangan terutama untuk pakan ternak. Sampel biostarter dianalisa di Laboratorium Mikrobiologi Fakultas Teknologi Pertanian, Universitas Udayana, Denpasar.

\section{HASIL DAN PEMBAHASAN}

Biostarter adalah suatu larutan yang berisi mikroorganisme pendegradasi/pengurai yang berguna untuk menguraikan limbah organik. Biostarter dapat dibuat sendiri dari limbah organik yang tersedia di lingkungan sekitar yang merupakan potensi lokal, seperti limbah buah dan daun. Dengan fermentasi selama 1-2 minggu di dalam alat fermentor, biostarter sudah bisa digunakan. Hasil analisis laboratorium menunjukkan bahwa kandungan bakteri asam laktat (BAL) pada biostarter dari limbah buah sebanyak $8 \times 10^{6} \mathrm{CFU} / \mathrm{ml}$, sedangkan yang dibuat dari limbah daun murbay dan bunga gemitir ( mery gold ) sebanyak 6,95 x $10^{6} \mathrm{CFU} / \mathrm{ml}$. Kedua biostarter ini tidak mengandung E.colli dan Salmonela sehingga aman diberikan pada ternak sebagai probiotik. Jadi, 
kedua biostarter ini bersifat multi fungsi, bisa sebagai fermentor dalam pembuatan pupuk cair dari urine menjadi biourine dan membuat pupuk padat dari kotoran ternak dan limbah pertanian, serta bisa diaplikasikan pada ternak (melalui air minum dan pakan ternak dalam bentuk silase). Selain sebagai pupuk, biourine juga bisa berfungsi sebagai biopestisida. Untuk biopestisida, biourine bisa dicampur dengan bahan-bahan alami yang mengandung racun, seperti umbi gadung, buah maja, tembakau, dan lain-lain yang bisa diperoleh dari lingkungan sekitar.

Biostarter yang diproduksi oleh kelompok tani Setia Makmur Desa Antapan sudah biasa dimanfaatkan oleh petani/peternak di desa ini dan juga sudah dijual dan pernah dipajang di stand pameran di Denpasar. Proses pembuatan biostarter dan kemasan produk ditampilkan pada Gambar 1.

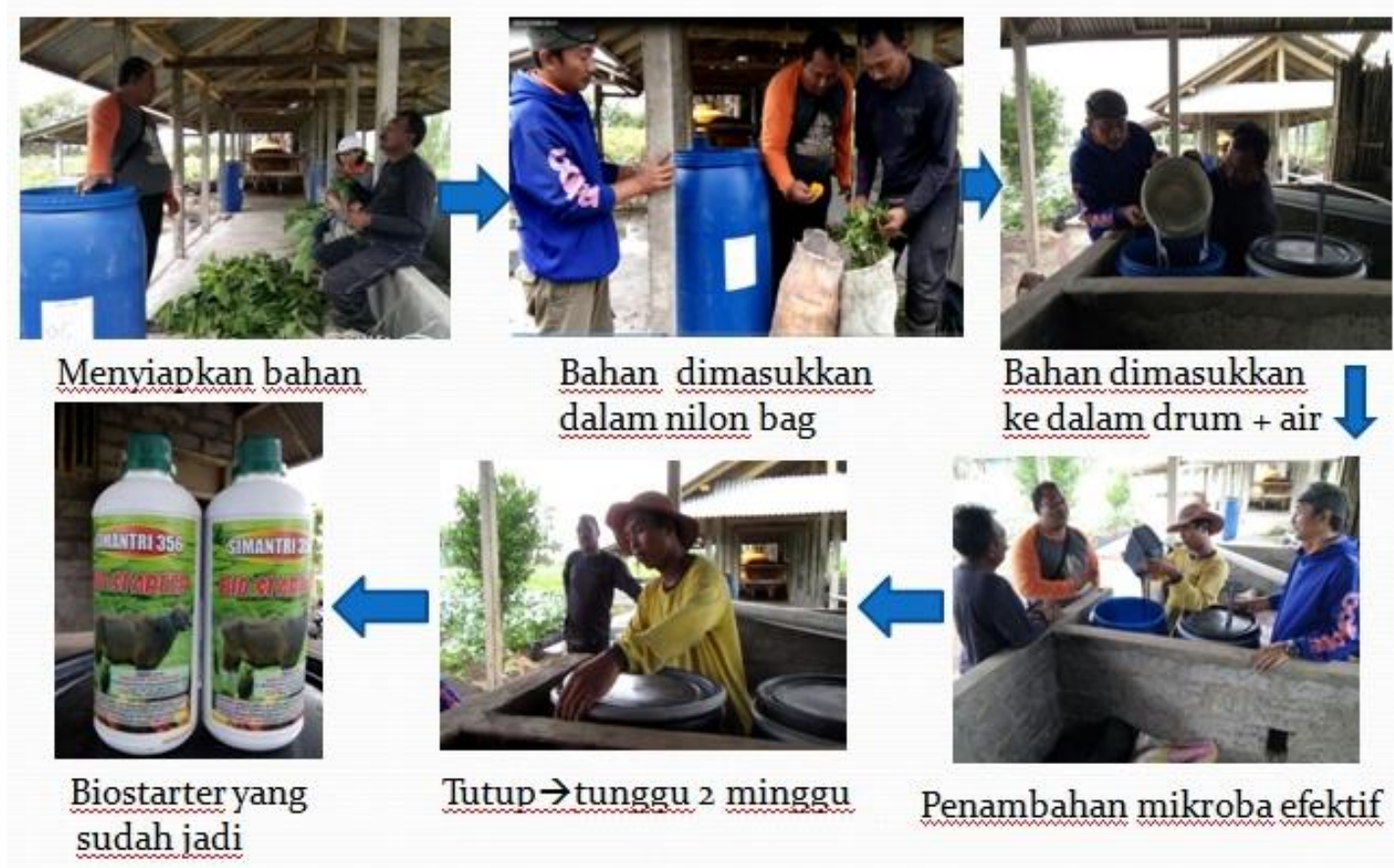

Gambar 3.1. Proses pembuatan biostarter

Proses pembuatan biostarter pada Gambar 1 sangat mudah dilaksanakan, demikian pula bahanbahan yang digunakan bisa berasal dari berbagai limbah organik. Pembuatan biostarter secara mandiri adalah salah satu upaya untuk menekan biaya produksi dalam usaha pertanian yang sekaligus menambah nilai guna dari limbah yang biasanya terbuang percuma. Selain itu, pemanfaatan limbah juga dapat menjaga kebersihan lingkungan.

\section{KESIMPULAN}

Dari hasil kegiatan ini dapat disimpulkan bahwa kelompok tani "Setia Makmur" di Desa Antapan sudah mampu dan terampil dalam membuat biostarter berbasis limbah buah dan daun. Biostarter dari limbah buah memiliki kualitas yang lebih baik dibanding limbah daun karena mengandung bakteri asam laktat yang lebih banyak, yang berfungsi untuk menekan pertumbuhan bakteri pathogen.

\section{UCAPAN TERIMA KASIH}


Penulis mengucapkan terima kasih kepada Direktorat Riset dan Pengabdian kepada Masyarakat, Dirjen DIKTI melalui Lembaga Penelitian dan Pengabdian masyarakat Unud, dan Pemda Kabupaten Tabanan atas dana yang diberikan sehingga pengabdian masyarakat berjalan dengan baik.

\section{DAFTAR PUSTAKA}

Anon. 2015. Profil Pembangunan Desa Antapan, Kecamatan Baturiti Kabupaten Tabanan.

[BPS] Badan Pusat Statistik. 2015. Kecamatan Baturiti dalam Angka tahun 2015. Badan Statistik Kabupaten Tabanan

Sardiana, I.K., I.M. Adnyana, I.B.P. Manuaba and I.G.A.M S Agung. 2014. Soil Organic Carbon, Labile Carbon and Organic Carbon Storage under Organic and Conventional Systems of Chinese Cabbage in Baturiti, Bali Indonesia. Journal of Biology, Agriculture and Healthcare. Vol. 4. No. 21. Pp. 63-71 